\title{
Keragaman Pangan dan Tingkat Kecukupan Energi serta Protein Pada Balita
}

\section{Dietary Diversity, Energy and Protein Adequacy in Children}

\author{
Dwi Putri Pangesti Suryo Andadari ${ }^{* 1}$, Trias Mahmudiono ${ }^{1}$
}

\begin{abstract}
ABSTRAK
Latar Belakang: Pada masa balita membutuhkan asupan gizi yang mencukupi untuk menunjang proses tumbuh kembang tersebut. Kebutuhan gizi pada balita dapat dipenuhi dengan mengonsumsi makanan yang beragam. Pemenuhan pangan yang cukup tercermin dari ketersediaan pangan yang cukup. Sumber daya pertanian dan perikanan seperti tambak memiliki potensi untuk menyediakan sumber pangan.

Tujuan: Tujuan penelitian ini untuk menganalisis perbedaan keragaman pangan dan tingkat kecukupan energi dan protein pada balita di wilayah pertanian dan tambak.

Metode: Penelitian cross sectional ini menggunakan sampel sebanyak 55 balita dengan ibu/pengasuh sebagai responden. Sampel diambil menggunakan proportional random sampling. Keragaman pangan dinilai menggunakan Individual Dietary Diversity Score (IDDS) dan dinilai dengan kriteria minimum konsumsi 10 gram. Data konsumsi pangan dikumpulkan menggunakan food recall $2 \times 24$ jam kemudian dikonversi dibandingan dengan Angka Kecukupan Gizi (AKG) untuk mendapatkan Tingkat Kecukupan Energi dan Tingkat Kecukupan Protein. Data dianalisis menggunakan Mann Whitney Test. Hasil: Hasil penelitian menunjukkan bahwa balita di wilayah pertanian tergolong keragaman pangan rendah dan balita di wilayah tambak tergolong keragaman pangan sedang $(p=0,024)$. Balita di wilayah pertanian maupun tambak tergolong tingkat kecukupan energi kurang $(p=0,588)$ dan tingkat kecukupan protein $(p=0,459)$.

Kesimpulan: Terdapat perbedaan keragaman pangan minimum konsumsi 10 gram diterapkan pada balita di wilayah pertanian dan tambak dan tidak terdapat perbedaan kecukupan energi serta protein pada balita di wilayah pertanian dan tambak.
\end{abstract}

Kata Kunci: keragaman pangan, kecukupan energi dan protein, agroekologi pertanian, agroekologi tambak 


\begin{abstract}
Background: Childrens needs adequacy nutrients to support the growth process. Nutritional needs in children period can be fullfiled by consuming a variety of foods. Agricultural and pond dominated area can to provide adequate food availability.

Objectives: The purpose of this study is to analyze the differences of dietary diversity and the level of energy and protein adequacy in children in agricultural and pond dominated areas.

Method: This cross sectional study design and samples are 55 children under five years with the mothers/babysitters as respondents. Samples are taken using proportional random sampling. Dietary diversity are assessed using Individual Dietary Diversity Score (IDDS) with the criteria considered to consume if the amount minimum 10 grams. Adequacy energy and protein is assessed using food recall $2 \times 24$ hours and continued by compared with AKG. The differences of dietary diversity, energy ad protein adequacy rates are analyzed using Mann Whitney Test.

Results: The results shows that children in agricultural area classified low dietary diversity and middle dietary diversity in children pond dominated area $(p=0.024)$. Children in agricultural and pond dominated areo classified less energy adequate (0.588) and more protein adequacy $(0.459)$.

Conclusion: There is difference of dietary diversity at children in agricultural and pond dominated area and ther is no difference of energy and protein adequacy in children in agricultural and pond dominated area.
\end{abstract}

Keywords: dietary diversity, Energy and protein adequacy, agricultural agroecology, pond dominated agroecology

\footnotetext{
*Koresponden:

dwiputri.psa@gmail.com

${ }^{1}$ Departemen Gizi Kesehatan, Fakultas

Kesehatan Masyarakat-Universitas Airlangga
} 


\section{PENDAHULUAN}

Masa balita merupakan masa di mana terjadi proses pertumbuhan dan perkembangan, baik secara fisik maupun motorik ${ }^{1}$. Pemberian makanan dalam jumlah yang tepat dengan pemilihan jenis makanan yang berkualitas dapat menunjang tumbuh kembang balita menjadi optimal. Pengenalan dan pemberian makanan yang beragam kepada balita perlu dilakukan sejak dini karena setiap bahan makanan mengandung zat gizi yang berbeda ${ }^{2}$. Makanan yang beragam tersebut terdiri dari makanan pokok, lauk pauk, sayuran dan buah-buahan. Selain itu, dalam mengonsumsi makanan perlu diperhatikan jumlah dan jenisnya agar sesuai dengan kebutuhan tubuh? ${ }^{3}$.

Penelitian keragaman pangan dengan indikator Dietary Diversity Score (DDS) yang dilakukan oleh Christina di Ghana mendapatkan hasil yang signifikan $(p<0,05)$, artinya keragaman pangan dapat meningkatkan asupan gizi dan status gizi pada $a k^{4}$. DDS didasarkan pada kelompok makanan dan baik digunakan untuk memprediksi kecukupan gizi pada individu 5 . Balita cenderung memiliki kebiasaan makan yang buruk, yakni hanya mengonsumsi satu jenis makanan saja sehingga dapat menyebabkan kekurangan gizi ${ }^{6}$.

Ketersediaan pangan pada Kabupaten Sidoarjo telah mencukupi, namun konsumsi pangan masyarakat belum memenuhi prinsip beragam dan bergizi seimbang ${ }^{7}$. Hal ini dapat dilihat dari skor Pola Pangan Harapan (PPH). Terdapat perbedaan skor PPH pada masingmasing agroekologi, pada agroekologi pertanian skor PPH sebesar 83,95 sedangkan pada agroekologi perikanan sebesar $87,32^{8}$. Sedangkan target skor PPH untuk Kabupaten Sidoarjo sebesar 95. Konsumsi energi dan protein pada agroekologi pertanian dan perikanan juga menunjukkan perbedaan, konsumsi energi terbesar masyrakat berada pada wilayah agroekologi perikanan dan termasuk dalam kategori lebih karena kecukupan energi sebesar $129,26 \%$ dari kecukupan pangan ideal sebesar $80-110 \%$ menurut Widyakarya Nasiolnal Pangan dan Gizi (WNPG) tahun 2012, sedangkan konsumsi protein terbesar masyarakat berada pada wilayah agroekologi pertanian dengan tingkat kecukupan mencapai $134 \%$ dari kecukupan pangan ideal ${ }^{8}$. Tujuan dari penelitian ini adalah untuk mengetahui perbedaan keragaman pangan dan kecukupan energi serta protein pada balita di wilayah pertanian dan tambak Kabupaten Sidoarjo.

\section{METODE}

Jenis penelitian yang digunakan dalam penelitian ini adalah observasional dengan desain penelitian cross sectional. Penelitian dilaksanakan di dua desa dengan pertimbangan bahwa desa tersebut memiliki potensi pangan. Desa Wonokasian merupakan desa yang memiliki potensi pada bidang pertanian dengan hasil pertanian yang beragam. Sedangkan Desa Kalanganyar merupakan desa yang memiliki luas tambak terbesar di Kabupaten Sidoarjo. Pengumpulan data dilakukan pada bulan Maret - Mei 2017. Sampel dalam penelitian adalah balita berusia 2-5 tahun. Besar sampel dalam penilitian adalah 55 balita dengan ibu/pengasuh balita sebagai responden. Sampel diambil berdasarkan proporsi jumlah balita yang ada di Desa Wonokasian dan Desa Kalanganyar. Cara pengambilan sampel menggunakan proportional random sampling. Sebanyak 30 balita di Desa Wonokasian dan 25 balita di Desa Kalanganyar yang terpilih menjadi sampel penelitian.

$$
\text { Pengumpulan data tentang }
$$
karakteristik keluarga seperti pendapatan, dan pengeluaran untuk pangan dilakukan dengan wawancara menggunakan kuesioner. Data tentang asupan makanan balita dikumpulkan menggunakan instrumen food Recall $2 \times 24$ jam dengan wawancara terhadap ibu/pengasuh balita. Data tentang asupan makanan kemudian diinput ke dalam Software Nutrisurvey kemudian dihitung dengan membandingkan rata-rata asupan dengan AKG. Penilaian keragaman pangan menggunakan instrumen Individual Dietary Diversity Score (IDDS) yang terdiri dari 9 kelompok pangan. Keragaman pangan dinilai berdasarkan hasil food recall $2 \times 24$ jam dengan memperhatikan berat makanan yang 
dikonsumsi minimum 10 gram, kemudian dikelompokkan menjadi tiga kategori menjadi keragaman pangan rendah jika $\leq 3$ kelompok pangan, keragaman pangan sedang jika 4-5 kelompok pangan, dan keragaman pangan tinggi jika $\geq 6$ kelompok pangan ${ }^{9}$. TKE dan TKP dikategorikan menjadi kurang $<80 \%$ AKG, baik $80-110 \%$ AKG, dan lebih $>110 \%{ }^{10}$.

\section{HASIL DAN PEMBAHASAN}

\section{Karakteristik Keluarga}

Hasil penelitian pada tabel 1 menunjukkan bahwa pendapatan pada rumah tangga di wilayah pertanian sebanyak 26,7\% tergolong dalam kuintil 5 yakni memiliki pendapatan perbulan $>3.000 .000$, sedangkan rumah tangga di wilayah tambak sebanyak $28 \%$ tergolong dalam kuintil 4 dengan pendapatan yang berkisar antara 2.500.001 3.000.000 perbulan. Pendapatan perbulan pada rumah tangga di wilayah pertanian lebih tinggi dibandingkan rumah tangga di wilayah tambak. Walaupun demikian, namun berdasarkan uji statistik didapatkan hasil bahwa tidak terdapat perbedaan yang signifikan $(p=0,173)$ antara pendapatan rumah tangga di wilayah pertanian dan tambak.
Rumah tangga dapat mengakses makanan dengan adanya pendapatan, sehingga dapat dikatakan bahwa pendapatan merupakan faktor yang penting ${ }^{2}$. Pendapatan yang tinggi dapat mempengaruhi rumah tangga dalam hal daya beli terhadap pangan sehingga dapat mempengaruhi keragaman pangan yang dikonsumsi dalam rumah tangga tersebut $^{11}$.

Pengeluaran untuk pangan rumah tangga di wilayah pertanian sebanyak $26,7 \%$ tergolong dalam kuintil 5 (>1.654.500), sedangkan rumah tangga di wilayah tambak sebanyak 44\%. Didapatkan hasil bahwa pendapatan rumah tangga lebih tinggi pada rumah tangga di wilayah pertanian, sedangkan pengeluaran untuk pangan lebih tinggi pada rumah tangga di wilayah tambak. Berdasarkan uji statistik, didapatkan hasil bahwa terdapat perbedaan yang signifikan $(p=0,027)$ antara pengeluaran untuk pangan pada rumah tangga di wilayah pertanian dan tambak.

Pengeluaran untuk pangan adalah biaya yang dikeluarkan rumah tangga membeli pangan. Pengeluaran pangan tidak hanya bergantung pada pendapatan rumah tangga namun juga bergantung pada pengetahuan tentang gizi dan jumlah anggota keluarga ${ }^{11}$.

Tabel 1. Distribusi Karakteristik Keluarga

\begin{tabular}{|c|c|c|c|c|c|c|c|}
\hline \multirow{2}{*}{ Karakteristik Keluarga } & \multicolumn{2}{|c|}{ Pertanian } & \multicolumn{2}{|c|}{ Tambak } & \multicolumn{2}{|c|}{ Rata-rata (Rp) } & \multirow{2}{*}{ P-value } \\
\hline & $\mathrm{n}$ & $\%$ & $\mathbf{n}$ & $\%$ & Pertanian & Tambak & \\
\hline \multicolumn{8}{|l|}{ Pendapatan Rumah Tangga } \\
\hline Kuintil $1(<1.620 .000)$ & 4 & 13,3 & 3 & 12 & & & \\
\hline Kuintil $2(1.620 .001-2.000 .000)$ & 7 & 23,3 & 6 & 24 & & & \\
\hline Kuintil $3(2.000 .001-2.500 .000)$ & 6 & 20 & 6 & 24 & 2.772 .300 & 2.568 .000 & 0,173 \\
\hline Kuintil $4(2.500 .001-3.000 .000)$ & 5 & 16,7 & 7 & 28 & & & \\
\hline Kuintil $5(>3.000 .000)$ & 8 & 26,7 & 3 & 12 & & & \\
\hline \multicolumn{8}{|l|}{ Pengeluaran untuk Pangan } \\
\hline Kuintil $1(<1.052 .000)$ & 6 & 20 & 2 & 8 & & & \\
\hline Kuintil $2(1.052 .001-1.186 .000)$ & 7 & 23,3 & 1 & 4 & & & \\
\hline Kuintil $3(1.186 .001-1.427 .000)$ & 7 & 23,3 & 6 & 24 & 1.362 .866 & 1.537.240 & 0,027 \\
\hline Kuintil $4(1.427 .001-1.654 .500)$ & 6 & 20 & 5 & 20 & & & \\
\hline Kuintil 5 (>1.654.500) & 4 & 26,7 & 11 & 44 & & & \\
\hline
\end{tabular}


Tabel 2. Keragaman pangan dan Tingkat Kecukupan Energi serta Protein

\begin{tabular}{|c|c|c|c|c|c|c|c|}
\hline \multirow{2}{*}{ Keragaman Pangan } & \multicolumn{2}{|c|}{ Pertanian } & \multicolumn{2}{|c|}{ Tambak } & \multicolumn{2}{|c|}{ Rata-rata (Rp) } & \multirow{2}{*}{ p-value } \\
\hline & $\mathrm{n}$ & $\%$ & $\mathbf{n}$ & $\%$ & Pertanian & Tambak & \\
\hline Rendah & 18 & 60 & 7 & 28 & \multirow{3}{*}{3,6} & \multirow{3}{*}{4,2} & \multirow{3}{*}{0,024} \\
\hline Sedang & 10 & 33,3 & 15 & 60 & & & \\
\hline Tinggi & 2 & 6,7 & 3 & 12 & & & \\
\hline \multicolumn{8}{|l|}{ Kecukupan Energi } \\
\hline Kurang & 19 & 63,3 & 14 & 56 & \multirow{3}{*}{72,8} & \multirow{3}{*}{72,04} & \multirow{3}{*}{0,339} \\
\hline Baik & 10 & 33,3 & 10 & 40 & & & \\
\hline Lebih & 1 & 3,3 & 1 & 4 & & & \\
\hline \multicolumn{8}{|l|}{ Kecukupan Protein } \\
\hline Kurang & 2 & 6,7 & 2 & 8 & \multirow{3}{*}{135,1} & \multirow{3}{*}{135,68} & \multirow{3}{*}{0,987} \\
\hline Baik & 11 & 36,7 & 6 & 24 & & & \\
\hline Lebih & 17 & 30,9 & 17 & 68 & & & \\
\hline Asupan Energi & & & & & 987 & 893,2 & 0,958 \\
\hline Asupan Protein & & & & & 29,56 & 27,32 & 0,432 \\
\hline
\end{tabular}

\section{Keragaman Pangan}

Hasil penelitian pada tabel 2 menunjukkan bahwa balita yang tergolong dalam keragaman pangan rendah sebanyak $60 \%$ di wilayah pertanian dan sebanyak $60 \%$ balita di wilayah tambak tergolong dalam keragaman pangan sedang. Berdasarkan hasil uji statistik didapatkan hasil bahwa terdapat perbedaan yang signifikan antara keragaman pangan pada balita di wilayah pertanian dan tambak Kabupaten Sidoarjo $(p=0,024)$.

Keragaman pangan dipengaruhi oleh dua faktor, yakni faktor internal dan faktor eksternal. Faktor internal yang mempengaruhi keragaman pangan adalah pendapatan, pengetahuan gizi, budaya dan religi, serta preferensi. Faktor eksternal diantaranya adalah produksi, ketersediaan, dan distribusi bahan makanan ${ }^{12}$. Rumah tangga di wilayah pertanian memiliki pendapatan yang lebih tinggi jika dibandingkan dengan rumah tangga di wilayah tambak, namun pengeluaran pangan rumah tangga di wilayah tambak lebih tinggi dibandingkan rumah tangga di wilayah pertanian.

Pendapatan rumah tangga dapat memengaruhi keragaman pangan yang dikonsumsi, artinya semakin tinggi pendapatan maka semakin tinggi pula keragaman pangan ${ }^{13}$. Hal ini berbeda dengan hasil penelitian yang dilakukan di Kabupaten Cilacap yang mendapatkan hasil bahwa pengeluaran rumah tangga untuk pangan berkorelasi negatif dengan pendapatan, hal ini berarti bahwa semakin tinggi pendapatan maka semakin rendah biaya yang dikeluarkan rumah tangga untuk pangan karena sebagian besar pendapatannya digunakan untuk memenuhi kebutuhan non pangan ${ }^{14}$.

Dari gambar 1 dapat disimpulkan bahwa konsumsi pangan balita di wilayah tambak berasal dari 9 kelompok pangan yakni makanan berpati, sayuran hijau, sayuran \& buah kaya vitamin A, sayuran\&buah lain, daging organ (jeroan), daging \& ikan, telur, kacang-kacangan\&biji-bijian serta susu dan olahannya. Sedangkan konsumsi pangan balita di wilayah pertanian hanya berasal dari 7 kelompok pangan. Kelompok pangan yang tidak dikonsumsi oleh balita di wilayah pertanian adalah sayuran hijau dan daging organ (jeroan). Hal ini menunjukkan bahwa preferensi balita terhadap kelompok pangan tersebut rendah. Balita di wilayah agroekologi pertanian lebih banyak mengonsumsi susu. Konsumsi susu tinggi pada balita di wilayah agroekologi pertanian dipengaruhi oleh konsumsi balita terhadap makanan beratnya. Balita di wilayah agroekologi pertanian cenderung memiliki nafsu makan terhadap makanan berat. Orang tua akan memberikan susu dalam jumlah yang lebih apabila anak mengalami kesulitan makan ${ }^{15}$. Faktor kesukaan pangan juga dapat mempengaruhi keragaman pangan. Kesukaan terhadap pangan merujuk pada daya terima yang dapat dipengaruhi oleh kebiasaan makan balita ${ }^{11}$. 


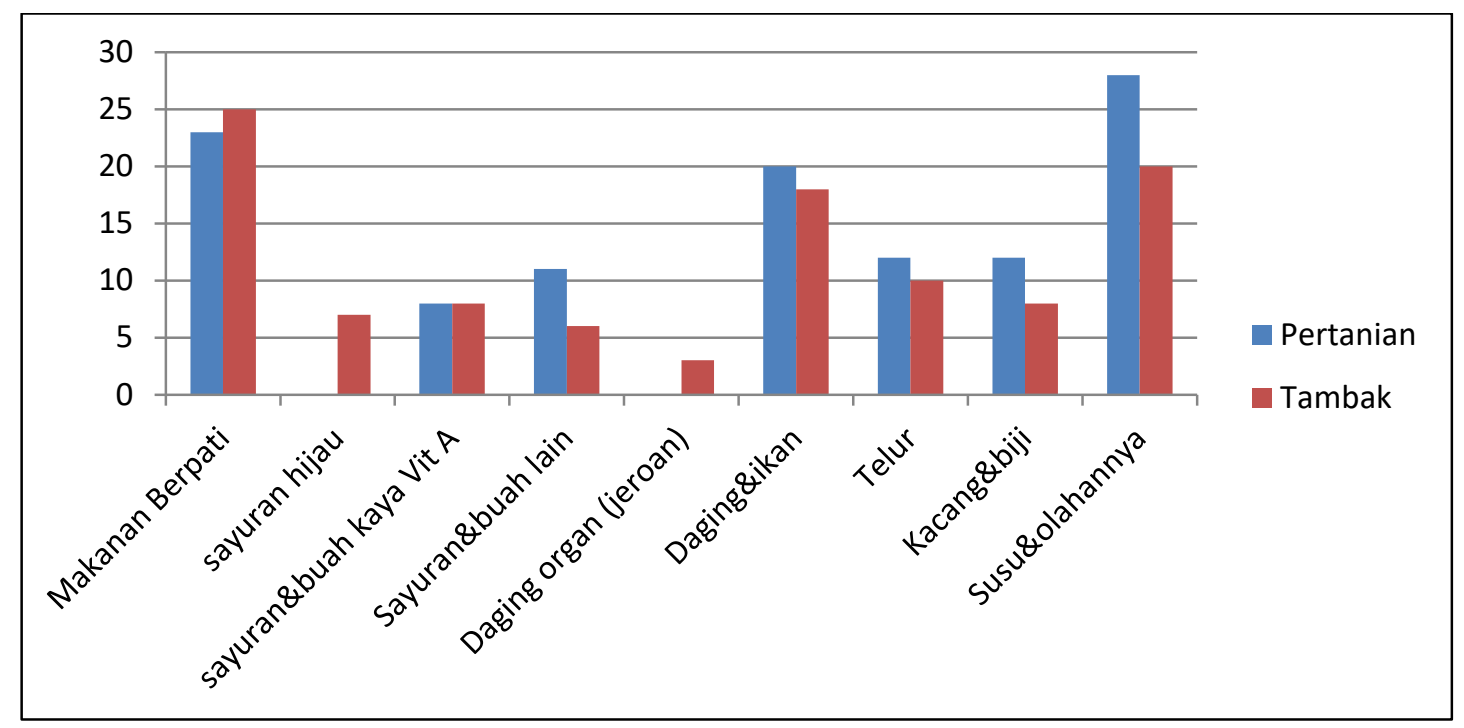

Gambar 1. Kelompok Pangan yang Dikonsumsi Balita

\section{Kecukupan Energi dan Protein}

Kecukupan energi pada balita di masing-masing wilayah pertanian dan tambak sebagian besar adalah kurang. Dari hasil penelitian menunjukkan bahwa rata-rata kecukupan energi pada balita di wilayah pertanian dan tambak tidak jauh berbeda yakni rata-rata kecukupan energi untuk wilayah pertanian sebesar $72,8 \%$ dan tambak sebesar $72,04 \%$ dengan asupan rata-rata 987 kkal di wilayah pertanian dan 893,2 kkal di wilayah tambak. Namun sebanyak 63,3\% balita di wilayah pertanian dan $56 \%$ balita di wilayah tambak memiliki kecukupan energi kurang. Berdasarkan uji statistik didapatkan hasil bahwa tidak terdapat perbedaan yang signifikan antara kecukupan energi $(p=0,588)$ pada balita di wilayah pertanian dan tambak, selain itu dilihat dari sisi asupan energi $(p=0,958)$ juga tidak terdapat perbedaan yang signifikan pada balita di wilayah pertanian dan tambak. Jumlah balita yang memiliki kecukupan energi kurang di wilayah pertanian lebih tinggi dibandingkan dengan balita di wilayah tambak, hal ini disebabkan hasil uji statistik menunjukkan bahwa makanan yang dikonsumsi oleh balita di wilayah tambak lebih beragam dibandingkan balita di wilayah pertanian. Hal ini sejalan dengan penelitian yang dilakukan oleh Christina yang mendapatkan hasil bahwa seiring dengan peningkatan keragaman pangan, maka konsumsi energi pada anak balita juga meningkat ${ }^{4}$.

Tingkat kecukupan protein pada balita di dua agroekologi tergolong dalam kategori lebih. Rata-rata kecukupan protein pada balita di wilayah pertanian sebesar $135,1 \%$ dan $135,68 \%$ di wilayah tambak dengan asupan rata-rata 29,56 di wilayah pertanian dan 27,32 di wilayah tambak. Pada tabel 2 nampak balita yang memiliki tingkat kecukupan protein kategori lebih di wilayah tambak mencapai $68 \%$ sedangkan pada balita di wilayah pertanian sebesar 30,9\%. Berdasarkan uji statistik didapatkan hasil bahwa tidak terdapat perbedaan kecukupan protein $(p=0,459)$ pada balita di wilayah pertanian dan tambak selain itu dilihat dari sisi asupan protein $(p=0,628)$ juga tidak terdapat perbedaan pada balita di wilayah pertanian dan tambak.

Kondisi tingkat konsumsi protein yang lebih tinggi dibandingkan konsumsi energi ini sejalan dengan penelitian yang dilakukan oleh Prasetyo dkk yang mendapatkan hasil bahwa anak balita memiliki tingkat kecukupan energi rata-rata $90 \%$ dan kecukupan protein rata-rata diatas $120 \%{ }^{16}$. Konsumsi protein yang lebih tinggi dibandingkan dengan konsumsi energi memberikan indikasi bahwa pola konsumsi pangan pada keluarga belum efisien. Kelebihan protein akan dimanfaatkan sebagai bahan bakar pengganti energi sedangkan fungsi utama dari perotein adalah sebagai zat pembangun dan pertumbuhan ${ }^{13}$. 
Tingkat konsumsi energi dan protein adalah konsumsi pangan dan menjadi indikasi dari perilaku pemilihan bahan pangan yang dapat dipengaruhi oleh banyak faktor ${ }^{13}$. Tingkat partisipasi tertinggi konsumsi pangan dari 9 kelompok pangan pada balita di wilayah pertanian dan tambak adalah makanan berpati dan susu. Beras memiliki partisipasi konsumsi yang tinggi pada balita. Hal ini sejalan dengan penelitian yang menyebutkan bahwa konsumsi sumber karbohidrat di dominasi oleh beras ${ }^{17}$. Kontribusi beras sebagai sumber energi menurun seiring dengan naiknya pendapatan dan semakin beragam pangan yang dikonsumsi akan mengurangi dominasi beras ${ }^{13}$. Kelompok pangan sumber protein hewani lebih tinggi dibandingkan protein nabati baik pada balita di wilayah pertanian maupun tambak. Jenis pangan sumber protein hewani yang menjadi preferensi balita adalah susu serta daging dan ikan, sedangan jenis pangan sumber protein nabati adalah tahu dan tempe. Tingginya konsumsi susu pada balita dipengaruhi oleh faktor kesukaan serta tingginya konsumsi daging dan ikan disebabkan oleh akses yang baik secara fisik maupun ekonomi.

Penelitian ini adalah penelitian pertama untuk mengevaluasi keragaman pangan dan kecukupan energi serta protein pada balita di wilayah pertanian dan tambak. Keterbatasan dalam penelitian ini adalah jumlah sampel yang sedikit dan untuk food recall sangat tergantung pada daya ingat responden sehingga kecenderungan untuk melaporkan konsumsinya lebih banyak atau lebih sedikit.

\section{KESIMPULAN}

Keragaman pangan, tingkat kecukupan energi dan protein lebih tinggi pada balita di wilayah tambak dibandingkan pertanian. Terdapat perbedaan yang signifikan antara keragaman pangan pada balita di wilayah pertanian dan tambak saat minimum konsumsi 10 gram diterapkan namun tidak terdapat perbedaan kecukupan energi dan protein pada balita di wilayah pertanian dan tambak.

\section{ACKNOWLEDGEMENT}

Terima kasih penulis berikan kepada seluruh dosen dan staf Prodi IImu Gizi Universitas Airlangga atas bimbingan yang diberikan kepada penulis.

\section{REFERENSI}

1. Adriani, M., Wirjatmadi, B. Peranan Gizi dalam Siklus Kehidupan. Jakarta: Kencana, 2012.

2. Ahmed., Fausat, Funmilola., John., Naphtali. Socioeconomic characteristics and food diversity amongst high income households: a case study of Maiduguri metropolis, borno state, Nigeria. American journal of social and management science. 2014; 5(1): 19-26

3. Kementerian Kesehatan RI. Pedoman Gizi Seimbang. Jakarta: 2014

4. Christina, A. Dietary Diversity is Associated with Nutrient Intakes and Nutritional Status of Children in Ghana. Asian Journal of Medical Sciences. 2011; 2(2011): 105-109

5. Zhao, Wenzhi., Yu, Kai., Tan, Shengjie., Zheng, Yingdong., Zhao, Ai., Wang, Peiyu., Zhang, Zumei. Dietary diversity scores: an indicator of micronutrient inadequacy instead of obesity for Chinese children. BMC Public Health. 2017; 17:440

6. Arisman, M.B. Gizi Dalam Daur Kehidupan: Buku Ajar Ilmu Gizi. Jakarta: Buku Kedokteran EGC, 2003.

7. Badan Ketahanan Pangan dan Pelaksana Penyuluhan. Laporan Akhir Penyusunan Skor Pola Pangan Harapan Kabupaten Sidoarjo Tahun 2015. Sidoarjo: 2015

8. Badan Ketahanan Pangan dan Pelaksana Penyuluhan. Laporan Akhir Penyusunan Skor Pola Pangan Harapan Kabupaten Kabupaten Sidoarjo Tahun 2016. Sidoarjo: 2016

9. FAO. Guidelines for Measuring Household and Individual Dietary Diversity. 2013. Available at http://www.fao.org/3/a-i1983e.pdf Diakses Pada Tanggal 30 Juni 2017 
10. Widyakarya Nasional Pangan dan Gizi (WNPG). Pemantapan Ketahanan Pangan dan Perbaikan Gizi Berbasis Kemandirian dan Kearifan Lokal. 2012. Jakarta: Lembaga Ilmu Pengetahuan Indonesia (LIPI)

11. Hardinsyah. Review Faktor Determinan Keragaman Konsumsi Pangan. Jurnal Gizi dan Pangan. 2007; 2(2): 55-74

12. Suryana, Achmad. Penganekaragaman konsumsi pangan dan gizi: Faktor pendukung peningkatan kualitas sumber daya manusia. Jurnal pangan. 2008; 17(3): 1-12

13. Cahyani, Gayatri I. Analisis faktor sosial ekonomi keluarga terhadap keanekaragaman konsumsi pangan berbasis agribisnis di kabupaten banyumas. Tesis. Semarang. Universitas diponegoro, 2008

14. Nilasari, ayu., Harisudin, Mohd., Widiyanto. Analisis hubungan pendapatan dengan proporsi pengeluaran pangan dan kecukupan gizi rumah tangga petani di kabupaten cilacap. E-jurnal agrista Vol 1 Edisi 1. 2013. Available at: http://agribisnis.fp.uns.ac.id/analisishubungan-antara-pendapatan-denganproporsi-pengeluaran-pangan-dankecukupan-gizi-rumah-tangga-petani-dikabupaten-cilacap. Diakses pada 9 Juli 2017

15. Anggraini, Y.D. Konsumsi Susu dan Faktor-Faktor Yang Mempengaruhinya Pada Balita di Wilayah Kelurahan Pekayon Kecamatan Pasar Rebo Jakarta Timur Tahun 2012. Skripsi. Depok: Universitas Indonesia

16. Prasetyo, T.J., Hardinsyah., Sinaga, Tiurma. Konsumsi pangan dan gizi serta skor pola pangan harapan (pph) pada anak usia 2-6 tahun di Indonesia. Jurnal gizi\&pangan. 2013; 8(3): 159-166

17. Apriani, $S \&$ Baliwati, YF. Faktor-faktor yang berpengaruh terhadap konsumsi pangan sumber karbohidrat di pedesaan dan perkotaan. Jurnal gizi dan pangan. 2011; 6(3): 200-207 